\title{
LIQUEFACTION OF COAL OF SHUBARKUL FIELD IN CATALYSTS PRESENCE
}

\author{
A.B. Agabekova , A. Tusiphan, K.A. Gudun, M.I. Baikenov, Zh.K. Kairbekov, K.A. Zhubanov
}

Describes the process of hydrogenation of the mixed system with the help of catalysts. The mixed system is a sample of coal and sample of Shubarkul shale. As a result, studies of this object installed main physical and chemical properties and the optimal parameters of the processes carried out.

\section{УДК 661.833.532}

\section{ТВЕРДЫЕ ОТЛОЖЕНИЯ И РАПА СОЛЯНЫХ ОЗЕР КАК ПЕРСПЕКТИВНОЕ СЫРЬЁ ДЛЯ ПОЛУЧЕНИЯ СУЛЬФАТА НАТРИЯ}

\author{
Ю. С. Анощенко ${ }^{1}$, В.П. Дзекунов ${ }^{1}$, Д.М.Кудабеков ${ }^{1}$, А.К. Уразалин ${ }^{2}$ \\ ${ }^{1}$ TОО «Объединенная химическая компания», г.Астана, anochshenko@ucc.com.kz, \\ dzekunov@ucc.com.kz, kudabekov@ucc.com.kz \\ ${ }^{2}$ Казахский национальный университет им. аль-Фараби, г.Алматы, urazalin@cfhma.kz
}

Дан анализ состояния балансовых запасов сульфата натрия в Казахстане. Рассмотрены применяемые в странах СНГ промышленные способы получения сульфата натрия из природного сырья.

Казахстан по количеству и разнообразию минерально-сырьевых ресурсов занимает одно из ведущих мест в мире. На базе разведанных запасов создана мощная нефтегазодобывающая, урановая и угольная отрасль, производства по добыче и переработке руд черных, цветных и благородных металлов, различных видов неметаллических полезных ископаемых.

По запасам свинца, цинка, меди, нефти, хрома, железа, марганца, олова, золота, фосфоритов, бора и калийных солей Республика входит в десятку ведущих стран мира /1/.

Фосфоритовые руды сосредоточены, в основном, в недрах бассейна Каратау, расположенного в Жамбылской и, частично, в Южно-Казахстанской областях.

Здесь выявлено до 50 месторождений фосфоритов с учтенными балансовыми запасами в количестве 5,0 млрд. тонн по руде и около 1,2 млрд. тонн пятиокиси фосфора. Эти запасы сосредоточены в шести крупнейших месторождениях бассейна и составляют до $1 / 3$ разведанных ресурсов фосфоритного сырья на территории СНГ и около $5 \%$ от разведанных мировых з запасов $/ 1 /$.

По разведанным запасам хрома Казахстан занимает второе место в мире и первое среди стран СНГ. Государственным балансом учтено 418951 тыс. тонн хромовых руд. Практически все они сосредоточены в Кампирайском массиве в Актюбинской области $/ 2 /$.

Поэтому в товарной структуре отечественной химической промышленности, благодаря наличию в республике значительных запасов фосфор- и хромсодержащего сырья, продукция на их основе составляет значительную часть в общем объеме производства отрасли.

В частности, ТОО «Казфосфат» осуществляется добыча и переработка фосфоритной руды, производство и реализация желтого фосфора и его производных, фосфорных минеральных удобрений и кормовых фосфатов, выпуск на основе минерального сырья промышленной продукции.

АО «Актюбинский завод хромовых соединений» является одним из трех предприятий в странах СНГ, на которых налажено производство хромовых соединений. На данном заводе на основе хромитовых руд, добываемых в области, налажено производство технического хромового ангидрида, технической окиси хрома, технического бихромата натрия, сульфата хрома (основного), технического бихромата калия и технической пигментной окиси хрома.

Вместе с тем, в Казахстане имеются значительные запасы и других видов минерального сырья, которые могут быть потенциальными источниками для организации в республике ряда новых видов химической продукции.

Наглядным примером этого является природный сульфат натрия.

В природе сульфат натрия встречается в составе многих минералов: астраханита $\left(\mathrm{Na}_{2} \mathrm{SO}_{4} \cdot\right.$ $\left.\mathrm{MgSO}_{4} \bullet 4 \mathrm{H}_{2} \mathrm{O}\right)$, тенардита $\left(\mathrm{Na}_{2} \mathrm{SO}_{4}\right)$, мирабилита $\left(\mathrm{Na}_{2} \mathrm{SO}_{4} \cdot 10 \mathrm{H}_{2} \mathrm{O}\right)$, глауберита $\left(\mathrm{Na}_{2} \mathrm{SO}_{4} \cdot \mathrm{CaSO}_{4}\right)$, глазерита $\left(\mathrm{Na}_{2} \mathrm{SO}_{4} \bullet 3 \mathrm{~K}_{2} \mathrm{SO}_{4}\right)$, беркеита $\left(2 \mathrm{Na}_{2} \mathrm{SO}_{4} \cdot \mathrm{Na}_{2} \mathrm{CO}_{3}\right)$ и др.

По морфологическому строению месторождения сульфата натрия разделяются на ископаемые тенардито-мирабилитовые и озерные; последние представляют собой периодические временные новые 
осадки мирабилита (или тенардита) и постоянные донные корневые отложения мирабилита, тенардита, астраханита и глауберита в виде пластов и линз под рассолами или илами озер.

В Казахстане астраханит встречается в виде донных корневых отложений в ряде сухих озер и водоемов повышенной солености. Например, средняя мощность пластов астряханита приаральских соляных озер (Джаксы-Клыч, Восточного и др.) составляет 2 метра.

Важное значение имеют месторождения сульфатных рассолов, пропитывающих погребенные солевые отложения. В республике встречаются сульфатные рассолы карстового происхождения, образовавшиеся в результате выщелачивания поверхностными и подземными водами погребенных солевых пород.

В Казахстане имеются месторождения природного сульфата натрия в виде твердых отложений и рапы многочисленных озер. Основными отечественными месторождениями являются озера Аральской группы. Значительные количества сульфата натрия содержатся в рапе озер Анж-Булат, Эбейты, Тениз и других.

В Приаральском районе расположено Джаксы-Клычское сульфатное месторождение, представленное группой сухих озер- «сульфатников»,

В Казахстане имеется ряд тенардитовых озер, в частности, на озере Малый Аж-Булат (Павлодарская обл.) в засушливые периоды образуется донный пласт тенардита. Это вторичный процесс, заключающийся в обезвоживании мирабилита под слоем концентрированной раны.

Практически неисчерпаемыми его источниками являются воды Каспийского, Аральского морей и оз. Балхаш. Солевой состав этих водоемов, не имеющих связей с океаном, сильно зависит от состава речных вод; последние же богаче сульфат-ионом, чем океанская вода.

В Казахстане на 1 января 2010 года балансовые запасы сульфата натрия составляли по категориям $\mathrm{A}+\mathrm{B}+\mathrm{C}_{1} 5776,2$ тыс. тонн, забалансовые 22811 тыс. тонн, в том числе в сырых солях по категориям $\mathrm{A}+\mathrm{B}+\mathrm{C}_{1} 5776,2$ тыс. тонн, забалансовые запасы 11065 тыс. тонн, забалансовые запасы в рапе 11746 тыс. тонн (таблица) /2/.

Таблица - Балансовые запасы сульфата натрия в Казахстане на 1 января 2010 года

\begin{tabular}{|c|c|c|c|c|}
\hline \multirow{2}{*}{$\begin{array}{l}\text { Месторождение } \\
\text { (синонимы) }\end{array}$} & \multirow[t]{2}{*}{ Местоположение } & \multirow[b]{2}{*}{$\begin{array}{l}\text { Компонент, } \\
\text { среднее } \\
\text { содержание } \\
\text { сульфата } \\
\text { натрия, } \%\end{array}$} & \multicolumn{2}{|c|}{ Запасы на 1января 2010 года } \\
\hline & & & $\mathrm{A}+\mathrm{B}+\mathrm{C}_{1}$ & Забалансовые \\
\hline Беткудукское & $\begin{array}{l}\text { Восточно- } \\
\text { Казахстанская обл., в } \\
70 \text { км к северо- } \\
\text { востоку от г. Зайсан }\end{array}$ & $\begin{array}{c}\text { Мирабилит, } \\
32,12\end{array}$ & $\begin{array}{c}282,4 \\
90,7\end{array}$ & \\
\hline \multirow{2}{*}{$\begin{array}{l}\text { Озера Большой Аж- } \\
\text { Булат } \\
\text { (Ажбулат) }\end{array}$} & \multirow{2}{*}{$\begin{array}{l}\text { Павлодарская обл. в } \\
60 \text { - } 65 \text { км к западу от } \\
\text { ж.д. станции Бурлы }\end{array}$} & Тенардит, 69,55 & & $\begin{array}{l}4713,0 \\
3278,0 \\
\end{array}$ \\
\hline & & Рапа, 8,92 & & $\begin{array}{l}11285,0 \\
11445,0 \\
\end{array}$ \\
\hline $\begin{array}{l}\text { Озеро Карашаган I } \\
\text { (озеро Карачаган I) }\end{array}$ & $\begin{array}{l}\text { Алматинская обл. в } \\
60 \text { км к северу от ж.д. } \\
\text { станции Лепсы } \\
\end{array}$ & Мирабилит, 40,0 & $\begin{array}{l}881,2 \\
352,5\end{array}$ & \\
\hline $\begin{array}{l}\text { Озеро Кашкан- } \\
\text { Тениз }\end{array}$ & $\begin{array}{l}\text { Жамбылская обл. в } \\
10 \text { км к северо- } \\
\text { западу от ж.д. } \\
\text { станции Кашкен- } \\
\text { Тениз }\end{array}$ & Тенардит, 93,0 & $\begin{array}{l}1620,0 \\
1337,0\end{array}$ & $\begin{array}{l}172,0 \\
142,0\end{array}$ \\
\hline \multirow[t]{2}{*}{$\begin{array}{l}\text { Озеро Малый Аж- } \\
\text { Булат }\end{array}$} & \multirow{2}{*}{$\begin{array}{l}\text { Павлодарская обл. в } \\
60 \text { - } 65 \text { км к западу от } \\
\text { ж.д. станции Бурлы }\end{array}$} & Тенардит, 74,6 & & $\begin{array}{l}822,0 \\
613,0 \\
\end{array}$ \\
\hline & & Рапа, 1,97 & & $\begin{array}{c}14829,0 \\
301,0 \\
\end{array}$ \\
\hline \multirow{2}{*}{$\begin{array}{l}\text { Месторождение в } \\
\text { районе озера } \\
\text { Жаксыклыш }\end{array}$} & \multirow{2}{*}{$\begin{array}{l}\text { Кзылординская обл. } \\
\text { в } 18 \text { км. к северу от } \\
\text { ж.д. станции }\end{array}$} & Мирабилит, 38,3 & $\begin{array}{l}470,0 \\
180,0\end{array}$ & $\begin{array}{l}4976,0 \\
1909,0\end{array}$ \\
\hline & & Тенардит, 91,7 & 12,0 & 253,0 \\
\hline
\end{tabular}




\begin{tabular}{|l|l|c|c|c|} 
(Озеро Джаксы - & Аральское море & 11,0 & 236,0 \\
\cline { 3 - 5 } & & $\begin{array}{c}\text { Сульфатные } \\
\text { Клыч) }\end{array}$ & 8715,0 & 15095,0 \\
& & Моли, 41,1 & 3581,0 & 4887,0 \\
\hline Озеро Сарабан Тук & Алматинская обл. в & Миралит, & 449,0 & \\
Бире & 60 км к северу от ж.д. & 49,89 & 224,0 & \\
(Карашаган II, & станции Лепсы & & & \\
Карачаган II) & & & & \\
\hline
\end{tabular}

Единицы измерения: сырые соли - тыс. тонн; рапа - тыс. м³; сульфат натрия - тыс. тонн

Сульфат натрия находит широкое применение в целлюлозно-бумажной и стекольной промышленности, в текстильной, мыловаренной и кожевенной отраслях промышленности, при производстве сернистого натрия, красителей и различных моющих средств и др.

В частности, содержание сульфата натрия в синтетических моющих средствах в зависимости от их назначения может составлять от 10 до 55\% (в стиральном порошке ТОО «Монета Дитердженте» (г. Шахтинск) на сульфат натрия приходится $38 \%$ ).

Однако, до настоящего времени в республике не уделяется должного внимания организации производства сульфата натрия из местного минерального сырья и поэтому его приходится в больших количествах завозить из-за рубежа.

Промышленные способы получения сульфата натрия основаны на использовании, как природного сырья, так и попутных или побочных продуктов химических производств.

Наиболее крупными производителями сульфата среди стран СНГ являются российские компании ОАО «Кучуксульфат» (Алтайский край), ОАО «Волжский Оргсинтез» (Волгоградская обл.) и ЗАО «Русский хром 1915» (Свердловская область) и ПО «Карабогазсульфат» (Туркмения).

В структуре производства сульфата натрия в странах СНГ более 80\% продукции вырабатывается из природного сырья, около $14 \%$ выпускается заводами по производству хромовых соединений, остальное другими производствами $/ 3 /$.

На территории стран СНГ в настоящее время разрабатывается только два месторождения природного сульфата натрия, и выпускают его два завода - ОАО «Кучуксульфат» (мощность по производству сульфата натрия составляет порядка 520 тыс. тонн в год) и ПО «Карабогазсульфат» (мощность по производству сульфата натрия 210 тыс. тонн в год).

В настоящее время в промышленности применяют следующие способы получения сульфата натрия из минерального сырья /4/:

- «плавление-выпаривание»;

- «плавление-высаливание»;

• комбинированный.

Все эти методы основаны на плавлении мирабилита при температуре свыше $32,4{ }^{\circ} \mathrm{C}$.

При нагревании до температуры превращения $\left(32,4^{\circ} \mathrm{C}\right)$ мирабилит плавится - разлагается на сульфат натрия и воду; освобождающаяся кристаллизационная вода растворяет часть сульфата натрия с образованием насыщенного раствора, а остальная часть его $(35,8 \%)$ остается в твердой фазе и может быть отделена отстаиванием, центрифугированием и т. д.

В дальнейшем при обычной температуре и малой влажности воздуха проводят выветривание полученной твердой фазы до образования порошкообразного сульфата натрия.

На ОАО «Кучуксульфат» и ПО «Карабогазсульфат» сульфат натрия получают из его минеральной формы - мирабилита по методу «плавление-выпаривание».

Технология получения сульфата натрия по методу «плавление - выпаривание» предусматривает плавление и последующую испарительную кристаллизацию минерала с использованием многокорпусных выпарных установок. При этом плавление осуществляется за счет теплоты вторичного пара выпарной установки с использованием суспензии в качестве теплоносителя. В частности, в ОАО «Кучуксульфат» плавление мирабилита ведут раствором сульфата натрия при $60{ }^{\circ} \mathrm{C}$ в горизонтальном реакторе с рамкой и шнековой мешалками.

Получение сульфата натрия по схеме «плавление-высаливание» основано на выделении соединения из рассолов, образующихся при плавлении, путём введения в них хлорида натрия или смешанных солей.

Процесс высаливания лучше реализуется при использовании чистого галита. Оптимальная температура в процессе высаливания составляет 60 - $65^{\circ} \mathrm{C}$. 
В случае использования подобной технологии практические результаты определяются степенью измельчения высаливающего агента.

Комбинированная схема включает плавление мирабилита и переработку получаемой жидкой фазы последовательно или параллельно способами выпаривания и высаливания.

В последние годы пристальное внимание разработке технологий получения сульфата натрия из местного природного сырья стали уделять в Узбекистане $/ 5 /$.

В частности, в Ташкентском химико-технологическом институте разработана технология производства сульфата натрия из природного мирабилита месторождения в Приаралье, расположенного недалеко от Кунградского содового завода. По расчетам узбекских специалистов, при организации производства сульфата в 50 тыс. тонн прибыль составит около 11 млн. сумов в год, а срок окупаемости вложенных затрат - не более одного года.

В Казахстане имеется достаточная минерально-сырьевая база для организации отечественного производства сульфата натрия, однако в настоящее время в республике системные работы по разработке технологий получения сульфата натрия из местного минерального сырья не производятся.

Поэтому с целью отработки технологий получения сульфата натрия из местного природного сырья представляет интерес проведение в республике комплексных научных исследований, включающих изучение физико-химических свойств залежей и разработку на их основе способов получения товарной продукции.

\section{Литература}

1. Постановление Правительства Республики Казахстан от 31 декабря 2010 года № 1530 «Об утверждении Программы по развитию минерально-сырьевого комплекса в Республике Казахстан на 2010 - 2014 годы».

2. http://www. geology.kz .

3. Сульфат натрия: обзор мирового производства, http://www.chemmarket.info/ru.

4. Демо-версия отчета «Обзор рынка сульфата натрия в СНГ, http://www.marketingbase.ru.

5. Аналитический портал химической промышленности, http://www.newchemistry.ru.

ТҰЗДЫ КӨЛДЕРДІҢ ҚАТТЫ ШӨГІНДІЛЕРІ МЕН АЩЫ СУЛАРЫ - НАТРИЙ СУЛЬФАТЫН АЛУДЫҢ ПЕРСПЕКТИВАЛЫҚ ШИКІЗАТЫ

Ю.С. Анощенко, В.П. Дзекунов, Д.М. Кудабеков, А.К. Өразалин

Қазақстандавы натрий сульфатының баланставы қјоры күйіне талдау берілген. ТМД елдерінде қолданылатын табиви шикізаттан натрий сульфатын алудың өнеркәсіптік әдісі құарастырылган.

\section{DEPOSITS AND BITTERN OF SALINE LAKES AS A PROMISING FEEDSTOCK FOR SODIUM SULFATE PRODUCTION}

\section{Y. Anochshenko, V. Dzekunov, D. Kudabekov, A. Urazalin}

The analysis of sodium sulfate geological reserves in Kazakhstan was given. Industrial processes used in CIS countries for producing sodium sulfate from natural raw materials were examined. 